\title{
Therapeutic alternatives and application of bacteriophages as a strategy in the use of bacterial diseases
}

\author{
Alternativas terapêuticas e aplicação de bacteriófagos como estratégia no uso de \\ antibióticos no tratamento de doenças bacterianas
}

\author{
Renata Dellalibera-Joviliano ${ }^{1}$, Samara Ariane de Melo $^{2}$, Henrique de Mello Remelli Ceni ${ }^{3}$
}

Dellalibera-Joviliano R, Melo SA, Ceni HMR. Therapeutic alternatives and application of bacteriophages as a strategy in the use of bacterial diseases / Alternativas terapêuticas e aplicação de bacteriófagos como estratégia no uso de antibióticos no tratamento de doenças bacterianas / Rev Med (São Paulo). 2020 Jan-Feb;99(1):88-95.

\begin{abstract}
Resistance to treatment of different microorganisms has been considered a major concern in the public health and medical fields. Pharmacological, microbiological, immunological approaches and the search for therapeutic alternatives have gained prominence in this area in order to understand the theme. In this context, the objective was to compile information correlating with alternative therapies with the problem of bacterial diseases in view of the multidrug resistance developed by antibiotic superbugs, since they represent the main treatment used in patients with these comorbidities. The electronic bases used as facilitators of the theme included Scielo, PubMed, MEDLINE and LILACS, period 2010-2019. From the active approaches, it is observed that the expansion of the therapeutic collection and prolongation of treatment to all periods of the natural process of bacterial diseases, avoiding the imminent seclusion regarding the offer of treatments to the most distinct cases of resistance, is considered a differential aspect. Still, aiming at solving this impasse, seeking effective therapeutic alternatives in the treatment of the most varied cases of bacterial diseases, and the possibility of its execution, either exclusively or mainly complementary to the use of antibiotics. Multiple intervention possibilities have been considered to include haemofiltration devices, quorum detection inhibitors, advanced immunotherapies, bacteriophage use, alternative efforts to limit virulence, integrative medicine measures such as homeopathy and herbal medicine. After the analysis, it was concluded that due to its efficacy and selective mechanism of action among the therapeutic alternatives found, the most promising was the application of bacteriophages.
\end{abstract}

Keywords: Bacteriophages; Drug resistance, Bacterial infections; Complementary therapies.
RESUMO: Resistências para o tratamento a diferentes microrganismos têm sido considerado uma grande preocupação em ordem de saúde pública e área médica. Enfoques farmacológicos, microbiológicos, imunológicos e busca de alternativas terapêuticas têm ganhado destaque nesta área a fim de compreender a temática. Neste contexto, objetivou-se compilar informações correlacionando-se com as terapias alternativas com a problemática das doenças bacterianas frente a multirresistência desenvolvida pelas superbactérias aos antibióticos, posto que representam o principal tratamento empregado em pacientes acometidos por essas comorbidades. As bases eletrônicas utilizadas como facilitadores da temática incluíram SciELO, PubMed, MEDLINE e LILACS, período 2010-2019. A partir das abordagens ativas, observa-se que ampliação do acervo terapêutico e prolongamento do tratamento a todos os períodos do processo natural de doenças bacterianas, evitando a iminente reclusão quanto a oferta de tratamentos aos mais distintos casos de resistência, é considerado um aspecto diferencial. Ainda, objetivando solucionar esse impasse, buscar de alternativas terapêuticas efetivas no tratamento dos mais variados casos de doenças bacterianas, e a possibilidade de sua execução, seja de modo exclusivo ou principalmente complementar ao uso de antibióticos. Múltiplas possibilidades de intervenção tem sido considerados a incluir dispositivos de hemofiltração, inibidores de detecção de quórum, imunoterapias avançadas, uso de bacteriófagos, esforços alternativos para limitar a virulência, medidas da medicina integrativa como a homeopatia e a fitoterapia. Após as análises, concluiu-se que devido a sua eficácia e mecanismo de ação seletivo entre as alternativas terapêuticas encontradas, a que se mostrou mais promissora foi a aplicação de bacteriófagos.

Descritores: Bacteriófagos; Resistência a medicamentos; Infecções bacterianas; Terapias complementares.

References to event work publications: $27^{\circ}$ SIICUSP, Ribeirão Preto, SP, September 27th of 2019; COMU-FMUSP, São Paulo, October 5th of 2019 (Award); COMA - FMRP/USP, Ribeirão Preto, October 26th of 2019.

Scientific Initiation Program - Research Center of the Department of Medicine, UNAERP Medical School, University of Ribeirão Preto.

1. PhD. Scientific Initiation Program - Research Center of the Department of Medicine, UNAERP Medical School, University of Ribeirão Preto. Orcid: https://orcid.org/0000-0002-5102.6724. E-mail: redellajov@gmail.com.

2. Department of Medicine, UNAERP Medical School, University of Ribeirão Preto. ORCID: https://orcid.org/0000-0003-2848-4767. E-mail: sammello97@gmail.com.

3. Department of Medicine, UNAERP Medical School, University of Ribeirão Preto. E-mail: henrique_remelli@hotmail.com, ORCID: https://orcid. org/0000-0002-2032-4606

Correspondence: Renata Dellalibera-Joviliano. Scientific Initiation Program - Research Center of the Department of Medicine, UNAERP Medical School, University of Ribeirão Preto. Avenida Costábile Romano, 2201, Ribeirão Prêto, SP, BR. CEP: 14096-900. 


\section{INTRODUCTION}

$\mathrm{T}$ wentieth century medicine had an essential advance in the treatment of infectious diseases, antibiotic therapy. In 1940, Alexander Fleming discovered the first biological antibiotic, penicillin, and along with it, he was already aware that resistance to this drug would be added to its use, so it must be accompanied. Contributing to this thought, after a year of this discovery, Barber proved in an experiment the ability of bacteria to resist penicillin from penicillinases that degrade such an antibiotic ${ }^{1}$.

Resistance mechanism transmission is now known to occur intrinsically or acquired through varying function gains through the production of new penicillin-binding proteins, enzymatic drug-altering mechanisms, altered therapeutic targets, efflux pumps. increased and changes in membrane permeability. Even though they are aware of their disadvantages, the Western world has adopted the widespread and indiscriminate use of antibiotics, which today corroborated that resistance to these drugs is one of the most serious health problems, not only because of the selective pressure exerted by their intensive use, as well as the process of developing new antimicrobial drugs ${ }^{1,2}$.
Explaining the practical reality of this problem, it is exemplified that in the United States (USA) annually, at least 2 million people are infected with resistant bacteria, and antimicrobial resistance is costly and has an estimated impact of 20 billion of dollars annually in that country. In Europe, the total annual cost associated with bacterial resistance is over $€ 1500$ million, a figure that may be underestimated. In addition, an estimate made by the World Health Organization is that by 2050 superbugs can account for about 10 million deaths per year and will cost the global economy approximately $\$ 84$ trillion ${ }^{1,3,4}$.

Aware of these problems, Brazil has been at the forefront since 2013, generating Patient Safety and Quality in Health Services (GVIMS) Newsletters. The first report from the National Resistance Monitoring Network included data from 908 hospitals in 26 of the 27 Brazilian federative units, with data on the resistance phenotypes of 19,009 microorganisms responsible for causing IPCSL (Primary Laboratory Bloodstream Infection) in Brazilian ICUs. From this information, it was confirmed that microbial resistance is a public health problem in all regions of the country. Figure 1 illustrates the percentage profile of resistant bacteria in ICU infected patients in the state of São Paulo ${ }^{5}$.

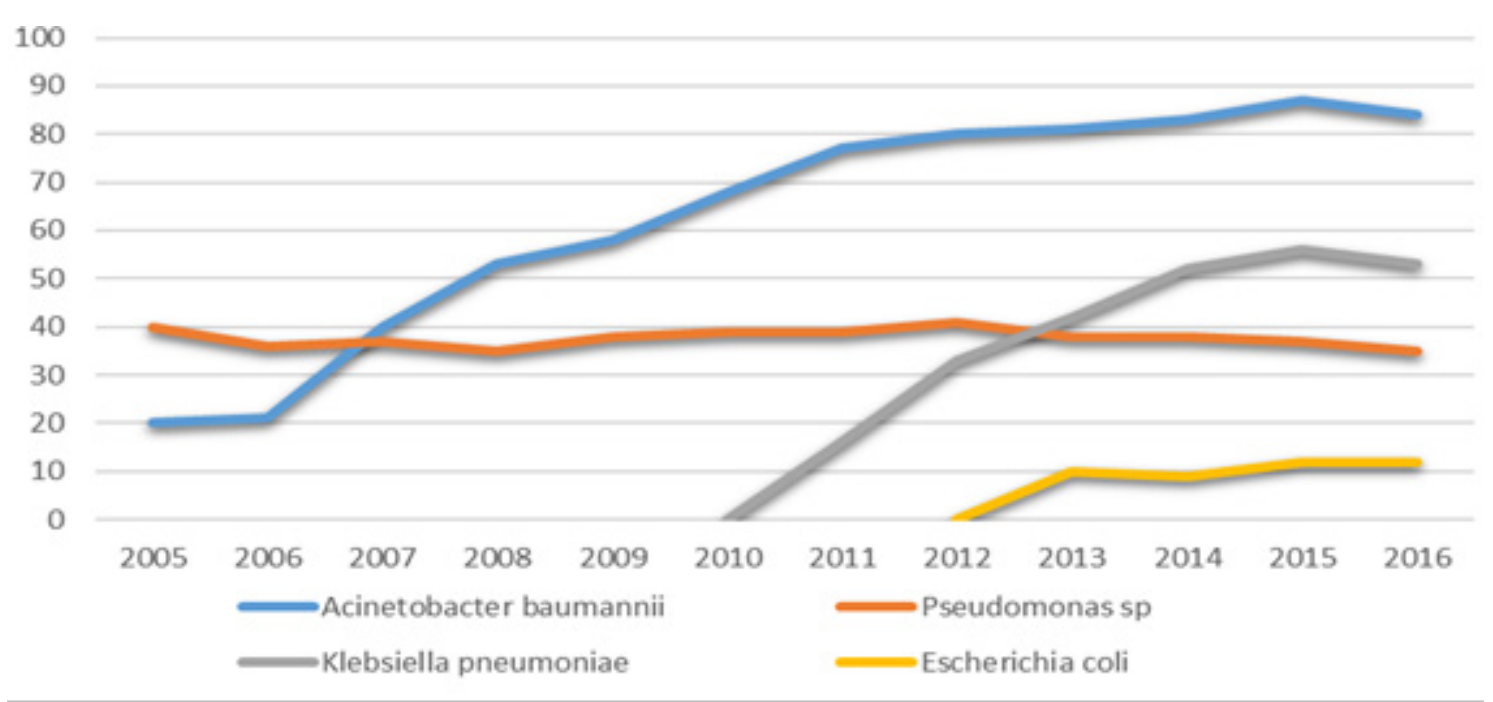

Figure 1: Percentage of resistant bacteria in infected patients in the ICUs of São Paulo State (Source: Epidemiological Surveillance Center / SP) $)^{5}$

If interventionist measures are not taken for the exposed reality, the therapeutic failure of antibiotics will culminate in increased days of hospitalization, morbidity, persistence of the infectious process with consequences on nosocomial infection, mortality and associated costs. This problem may become even more serious that a common infection becomes highly complex, becoming intractable, and interventional procedures, from surgery, chemotherapy, organ transplantation or neonatal care, are at risk of becoming impracticable ${ }^{1}$.

In addition to that, due to the low profitability and growing lack of interest in the laborious production of new antibacterials by the pharmaceutical industry, the choice of new therapeutic methods is extremely important due to their economic repercussions ${ }^{6}$.

Aware of the situation presented, and intending to 
contribute to the growing demand for new interventional measures in bacterial diseases, alternative ways to the use of antibiotics have gained power in the research market. Therefore, it would be necessary to seek solutions that would combat them as a whole, both in their incidence, through the introduction of preventive measures, and investing in different therapeutic methods, in cases that could not be prevented ${ }^{7}$.

\section{METHODS}

In this study, which follows the bibliographic review model, the objectives are achieved based on information collected in scientific articles, research sites such as CAPES, SciELO, Pubmed, CNPq and FAPESP platforms. It compiled the use of an updated theoretical framework from 2010 to 2019. Aiming to further investigate the sources of information, it was necessary to systematically divide the scientific articles from a flowchart identified in Figure 2, allowing for a prospective progress between the introduction. The bibliographical selection and the compilation of articles, expanding the production of the discussion and the conclusion. Descriptors used for the conduct of this study included: Bacteriophage, bacterial multidrug resistance, bacterial diseases, alternative therapies.
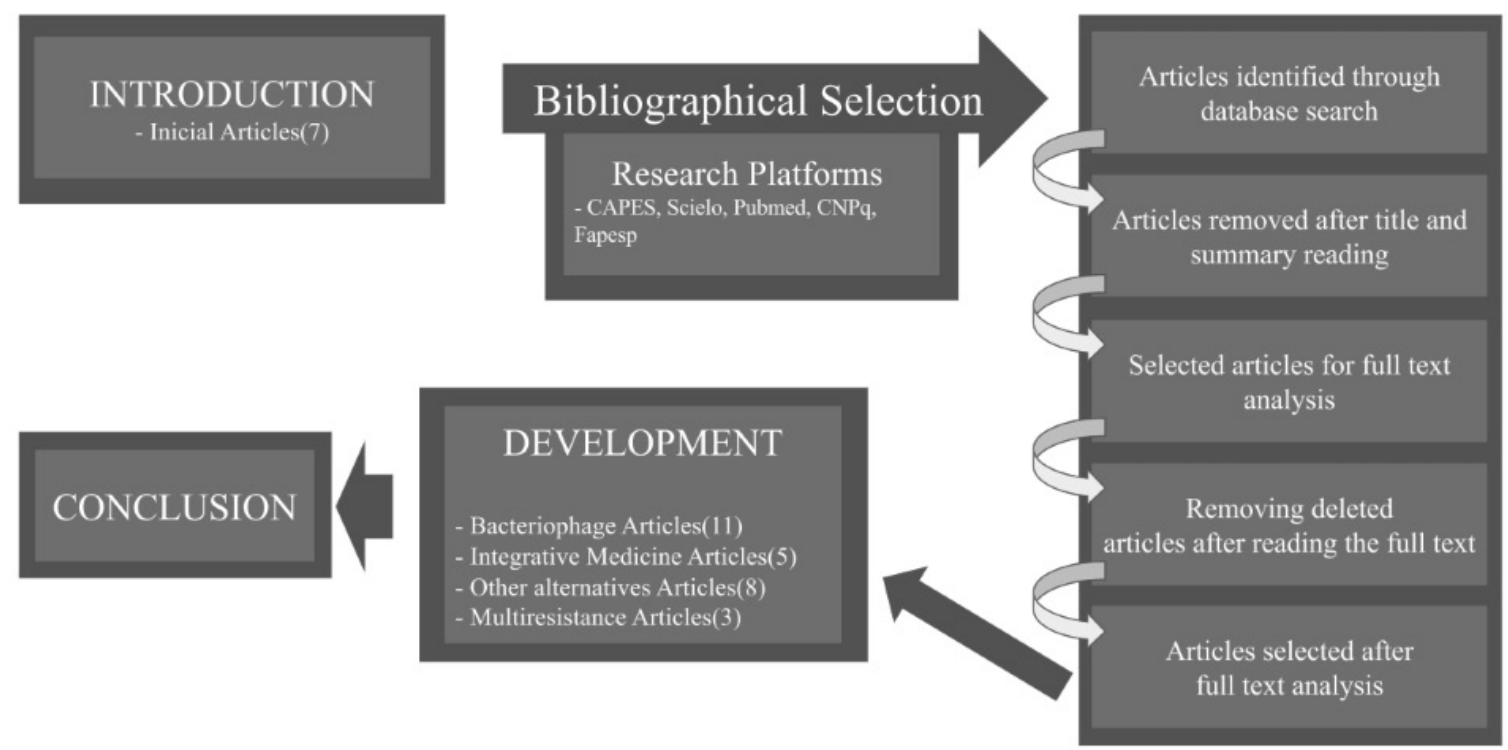

Figure 2: Flowchart elaborated from the methodology used for data collection of this study

\section{DEVELOPMENT}

To facilitate the understanding of the data obtained, it is possible to observe in Image 3 the elaboration of a flowchart where we identify the search for therapeutic alternatives to bacterial diseases that can cause even multidrug resistance. Thus, the pathological conditions involving bacterial diseases encouraged the incessant investigation for therapeutic measures that could be applied to bacterial diseases. We may consider that the search ceased in 1940 with Fleming's discovery of antibiotics, but at the same time the perception that along with these drugs, superbugs could develop into an even worse reality, multidrug resistance. Surrounded by this reality, it is possible to question whether Fleming's discovery culminated in the return to the search for other alternatives, in a scenario where bacterial diseases are still present and multidrug resistance gains even more frightening proportions than the initial one.

Motivated by the exploration of strategies for this topic, we found several possibilities for alternative interventions including hemofiltration devices, quorum detection inhibitors, advanced immunotherapies, alternative efforts to limit virulence, integrative medicine measures such as homeopathy and herbal medicine, but mainly the most promising one, the use of bacteriophages ${ }^{8}$. 


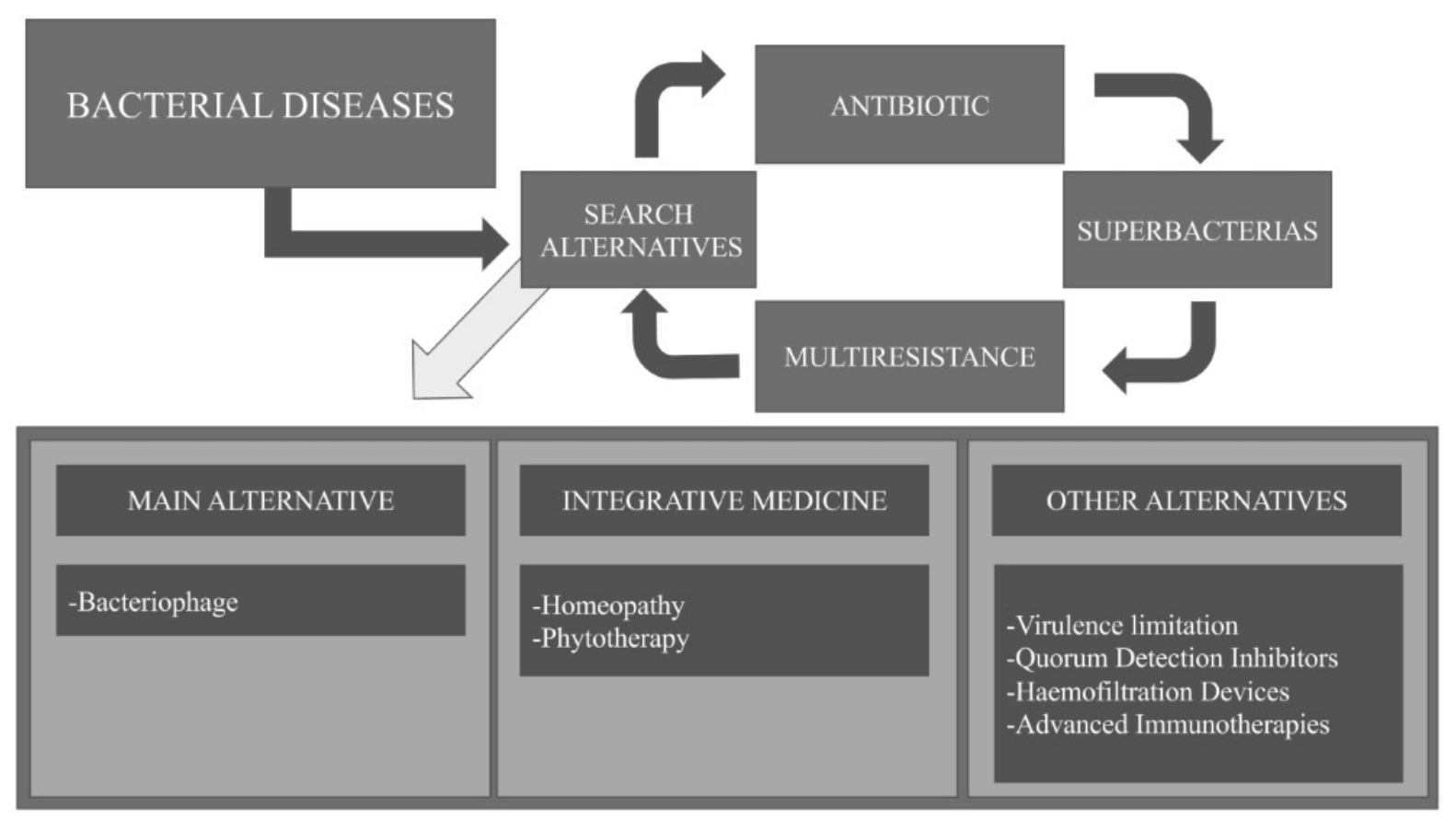

Figure 3- Flowchart containing alternative therapeutic strategies for bacterial diseases that can cause multidrug resistance

\section{Therapeutic alternatives}

Hemofiltration devices act as extracorporeal filters, aiming to allow the innate and adaptive host immune system to remove agents and their possible panresistent residues to microbial agents. Some of these devices simulate the action of the human spleen and are studied for the possible treatment of sepsis. They operate through magnetism, causing the opsonization of one or several types of microorganisms, sculpting a microfluid arrangement similar to the spleen and thus allowing the elimination of pathogens ${ }^{8,9}$.

As bacterial action in biofilms of chemical signal release and gene expression is subject to quorum detection, which allow the coordination of a collective behavior of bacteria, which act similar to multicellular organisms. Inhibiting agents of this detection represent a practical clinical benefit against multiresistant pathogens, that bacteria use a type of intercellular communication to alert pathogens about their collective bacterial concentration, which when elevated can change their transcription profiles to an invasive phenotype. Thus, quorum detection block has the ability to improve results in experimental models of systemic infection, representing another promising method for the treatment of bacterial diseases ${ }^{8,10,11,12}$.

Another therapeutic measure is advanced immunotherapies, which although it is not a new approach, can still be innovated by generating high affinity polyclonal and monoclonal human antibodies against a range of molecular targets is making them more attractive. Proof of this is that adjuvant active immunization with multiepitope vaccines, as well as monoclonal and polyclonal antibodies, as passive therapies against bacterial pathogens, is being developed, aiming to boost the host's cellular and humoral adaptive immunities, thus representing the possibility of use for prophylaxis or for pre- or post-exposure treatment. Several adjuvants are under investigation, including interleukin-7, macrophage and granulocyte colony stimulating factor, apoptosis inducing antibody, it is expected that such immunological adjuvants may benefit patients with sepsis-induced immunosuppression ${ }^{8,13}$.

Corroborating the other therapeutic alternatives are virulence limiting mechanisms, which are inhibitors of modified liposome-based cytotoxins, which capture a variety of bacterial toxins with cell membrane lysis capability. These liposomes serve as cell membrane chemoattractants to absorb cytotoxins, protecting human cells from injury. This non-antibiotic defense mechanism experimentally protects and could complement antimicrobial agents in the treatment of exotoxin-producing bacterial infections ${ }^{8}$.

\section{Integrative Medicine}

In Integrative Medicine homeopathy is formulated considering the Hippocratic concept, which is based on the idea that the disease is produced by the similar and by the similar the patient returns to health. From this, this practice is articulated by the association between medicine and pharmaceutical, which aims for minimum doses of medicine to stimulate the organic reaction to cure and thus prevent the aggravation of symptoms. This practice is based 
on the philosophical character that the manifestation of a disease present in the patient will also be present in a certain substance, so when administered to a healthy individual, it will present the patient's symptoms. Using this specific substance the homeopathic clinician will transform it into the necessary medicine by the dynamization method, which allows to reduce the toxic effects of the original substance and increase its healing potential. It is concluded from this that the drug has the power to make the body react immunologically, fighting these symptoms, seeking cure ${ }^{14}$.

A study by Furuta et al. ${ }^{15}$ involving samples of pediatric patients showed that children had a diagnosis of recurrent tonsillitis, which were divided into two doubleblind groups, where a group of 20 patients would receive homeopathic medicine and another group of 20 patients would receive a placebo. Both groups underwent through a daily treatment for 4 months. At the end of the study, among the group treated with homeopathic medicine, $22 \%$ of patients had acute tonsillitis and $78 \%$ did not, while in the placebo group $67 \%$ of patients had acute tonsillitis and $33 \%$ did not. This statistic demonstrates a greater efficacy favorable to the use of homeopathic treatment ${ }^{15}$.

In addition to that, the use of herbal medicine, effective in primary health care, is embodied by the use of medicinal plants in their pharmaceutical form, with the purpose of preventing or curing pathologies. For developing countries, where the rate of use of herbal medicines has about $80 \%$ of adherents, they need to have greater cultural acceptability and accessibility to treatment, to achieve high compatibility with the human body and minimize its side effects. Therefore, when compounds derived from medicinal plants are used to inhibit and destroy pathogens, they have infamous host cell toxicity and are therefore excellent for a new antimicrobial ${ }^{16}$.

It is necessary to understand that this alternative is one of the main resources of Alternative Medicine and that it has been used for a long time by the Brazilian population. Coupled with this, it is important to recognize its notoriety among patients who hardly have access to primary health care and also to the allopathic remedy due to its high $\operatorname{cost}^{17}$.

Nascimento-Junior et al. ${ }^{17}$ show that during the execution of a cross-sectional study involving 96 higher education professionals working in the Family Health Strategy Program, they are not able to disseminate information about alternative use as a treatment choice, regardless of the disease. In this study, we analyzed the perception of importance, use and indications of Medicinal and Herbal Plants. This reality culminates in the elimination of one more possibility that could be offered to patients looking for more natural and less costly treatment solutions, not only harming the service that could be better ${ }^{17}$.

The result was conflicting and it can be noted that a large part is not prepared to pass on information on the use of medicinal plants or prescribe herbal medicines to the population, and this ends up causing great harm to the service, because this Complementary and Alternative Medicine is a good option and generally have a lower $\operatorname{cost}^{18}$.

At the community level, urinary tract infection is the most common of infections, being more prevalent in women because of the ease that anal microorganisms have to reach the female urethra and result in this disease. An effective treatment method for this condition is to increase diuresis by administering diuretic substances, favoring an effective cleansing of crystallization nuclei and bacteria that may be in the urinary tract. In this regard, the use of herbal medicine through plants that have a promising character in increasing renal water excretion is relevant ${ }^{1,19}$.

\section{Bacteriophages}

Analyzing the lytic bacteriophages, their means of replication is through the insertion of their genetic material, which will lead to bacterial cellular machinery replicating the transmitted viral information. This occurs much faster than the bacteria itself. Having completed the process of synthesis and assembly of new phages, these will be released by bacterial cell lysis and will have the ability to initiate a new replication cycle. For this reason, natural control antimicrobial agents are considered ${ }^{1}$.

There is a great need for safe and effective antimicrobial treatment options, as antibiotics have limitations, such as poor penetration into bacterial biofilms and the growing emergence of resistant bacterial strains. As noted, the use of strictly lytic bacteriophages has played an active role in this research and has been suggested as an alternative or complement to conventional chemical antibiotics, allowing them to act as natural predators directly on bacteria. Antibiotic therapy with phages has great advantages compared to conventional chemical antibiotics, among these advantages is the great specificity that they have when replicating directly at the site of infection, being abundantly available where they are most needed and their dependence on the host bacteria to multiply, makes it exist only until it is exterminated $\mathrm{d}^{20,21,22}$.

Phage therapies can be differentiated in several ways, including their place of administration (topical, oral, systemic or even directly onto body tissues). In addition, phage delivery to intracellular pathogens, the most common being the administration of free phage or bacteria already infected with phage, is another mode of differentiation. They can also be genetically altered to deliver non-phage genes encoding specific antibacterial agents. In order to ascertain the effectiveness of bacteriophages in the bloodstream, it is possible to develop a phage cocktail with the host-specific phage formulation range by mixing two or more bacteriophages called "phage cocktails"22.

Comparing the therapeutic alternatives shows that the most promising was the bacteriophages, having the advantage of their long developmental period, similar to the antibiotic, but with lower cost and greater efficacy. In order 
to demonstrate its effectiveness, Schooley's ${ }^{23}$ data illustrate an intravenous infusion of $1.8 \mathrm{E}+04$ bacteriophages in a patient with a bacterial disease who was resistant to antibiotics. It is possible to observe that within 360 minutes after its use, the bacteriophage concentration reached level 0 , because its survival viability in the human organism is restricted to its reproduction within the bacteria ${ }^{23}$.

Thus, by acting on specific receptors of the diseasecausing microorganism, preventing their replication and survival in the host cell, both are exterminated. To ensure that this occurs in situ, the modification of the phage for its immunogenicity or even the selection of long-circulating phages has the ability to decrease its clearance by cells of the reticuloendothelial system (RES), corroborating a better action ${ }^{6,23}$.

In the fields of infectious diseases and gastroenterology, Sabino et al. ${ }^{24}$ show that phage therapy is a promising therapeutic tool against pathogenic bacteria. Randomized, placebo-controlled studies with phage therapy for gastroenterological diseases are ongoing ${ }^{24}$.

Bacteria may develop resistance to antibiotics. Even without changing genetically, bacteria can also exhibit tolerance to antibiotic treatments. Many antibiotics are also acting broadly as they can result in excessive modifications of the body's microbiomes. Particularly for antibiotics of last resort or in the treatment of extremely ill patients, antibiotics may also exhibit excessive toxicity. Antibiotics, however, remain the standard treatment for bacterial infections, and rightly so, because of their long record of antibacterial efficacy and infrequent side effects. Antibiotics do not successfully cure all treated bacterial infections, however, thus providing a utility for alternative antibacterial approaches. One such approach is the use of bacteriophages, bacterial viruses ${ }^{25}$.

This nearly 100-year-old anti-bacterial infection technology can be effective against antibiotic resistant or tolerant bacteria, including bacterial biofilms and persistent cells. Ideally, phages could be used in combination with standard antibiotics while maintaining their antibacterial pharmacodynamic activity, although antibiotics interfere with aspects of bacterial metabolism that are also required for the full activity of phage infection. Abedon (2019) through a literature review identified preclinical combined treatments with phages and antibiotics, with emphasis on antibiotic-susceptible bacterial targets. Evidence of antibiotic interference on phage infection activity, together with its inverse, suggests the antibacterial functioning of phages despite the presence of antibiotics ${ }^{25}$.

The prospects for endolysins are enhanced by the ability to design them; New endolysins can be developed with optimized stability, specificity and lytic function. Thus the growth of endolysin engineering and application requires a comprehensive understanding of the relationship between the biochemical, biophysical and bacteriolitic properties of enzymes. Love et al. ${ }^{26}$ report that bacteriophage endolysins have the potential to be a longterm antibacterial substitute for antibiotics with exogenous application of endolysins in some bacteria resulting in rapid cell lysis.

The high success rate and safety of phage therapy compared to antibiotics is partly due to its specificity for selected bacteria and the ability to infect only one species, serotype or strain. This mechanism does not cause the destruction of commensal bacterial flora. Phages are currently being used successfully in humans and animals in therapies directed at slow cure infections. They have also found application in the US to eliminate surface pathogens from animal and plant foods. At a time of increasing antibiotic resistance in bacteria and the resulting restrictions on antibiotic use, bacteriophages may provide an alternative means of eliminating pathogens ${ }^{27}$.

The effectiveness of phytotherapy and homeopathy is proven by numerous studies, showing to be superior to the isolated or combined use of the antibiotic. However, the expansion of its use requires the rupture of socio-cultural paradigms, such as the disbelief of its effectiveness by the population that prevents the full adhesion of these alternatives. For this, it is possible to follow its prodigious application in the Eastern World and make it a model to be followed in order to consolidate these practices in the Brazilian reality.

With regard to the other methods covered, such as use of hemofiltration devices, quorum detection inhibitors, virulence limiting devices and use of advanced immunotherapies, these methods still require a lot of research time and high investments, delaying their access to public. Moreover, they represent highly complex methods, which today would contribute to the restricted application of these alternatives, generating a population fractionation for their use, so it is desired that plausible ways to disseminate them to a larger number of people are studied.

\section{CONCLUSION}

Compiling the full picture of bacterial diseases, the solution to the initial project inquiry would include the pre-pathogenic period to prevent the exponential incidence of multidrug resistance. To this end, it is recommended that basic measures be taken at the primary prevention level in order to eradicate the sometimes unnecessary and excessive prescription of antibiotics that is made in the health area, and their banalization by professionals, which often allow them to spread. the belief that the use of these drugs can be rampant or even devalue the consequences they can cause. In addition, incorrect administration by patients, many of whom are unoriented and unaware of its complexity, discontinue treatment before its completion, consume alcohol concomitantly with the use of the drug and use prescription drugs when unfinished. 
Considering the cases in which multidrug resistance already exists, the application of alternative therapeutic measures to the use of antibiotics represents the consolidation of equity in the treatment of patients. Since there would be expansion in the collection of possible measures to be offered to each person according to their integral needs and considering the pathogenic phase in which they were inserted, and not according to a generic context. And despite the obstacles encountered in increasing resistance, bacteriophages along with the various other therapeutic alternatives play a major role in trying to reverse and eradicate the millions of multidrug resistance cases already in the world and generate a scenario of hope for their effectiveness. and its applicability.

COLLABORATIONS: Renata Dellalibera-Joviliano: teacher advisor; general orientation, revision, execution, general revision of the text. Henrique de Mello Remelli Ceni and Samara Ariane Melo: medical students and undergraduate students; data collection, methodology development, elaboration of the text integrating the article: elaboration of the article.

Conflict of Interest Statement: The authors declare no conflict of interest in this article proposed for publication.

\section{REFERENCES}

1. Rosa JEC. Multirresistência bacteriana - uma "nova" terapêutica: bacteriófagos [mestrado]. Covilhã: Universidade Beira Interior, Ciências da Saúde; 2015. Disponível em: https:// ubibliorum.ubi.pt/bitstream/10400.6/6448/1/4094_7905.pdf.

2. Centers for Disease Control and Prevention. Antibiotic resistance threats. United States: Department of Health and Human Services; 2013. Chap 1, p.11. Available from: https:// www.cdc.gov/drugresistance/pdf/ar-threats-2013-508.pdf.

3. Liu YY, Wang Y, Walsh TR, et al. Emergence of plasmidmediated colistin resistance mechanism, MCR-1 in animals and human beings in China: microbiological and molecular biological study. Lancet Infect Dis. 2016;16(2):161-8. doi: 10.1016/S1473-3099(15)00424-7.

4. Krake MEA, Stewardson AJ, Harbarth S. Will 10 million people die a year due to antimicrobial resistance by 2050 ? PLoS Med. 2016;13(11): e1002184. doi: 10.1371/journal. pmed.1002184.

5. Agência Nacional de Vigilância Sanitária. Plano nacional para a prevenção e o controle da resistência microbiana nos serviços de saúde. Brasília; 2017. Cap. 2. Disponível em: http://portal.anvisa.gov.br/documents/33852/271855/ Plano + Nacional + para $+\mathrm{a}+$ Preven $\% \mathrm{C} 3 \% \mathrm{~A} 7 \% \mathrm{C} 3 \% \mathrm{~A} 3 \mathrm{o}+\mathrm{e}+$ $\mathrm{o}+$ Controle + da + Resist $\%$ C3\%AAncia + Microbiana + nos $+\mathrm{S}$ ervi $\%$ C3\%A7os+de+Sa\%C3\%BAde/9d9f63f3-592b-4fe1$8 \mathrm{ff2}-\mathrm{e} 035 \mathrm{fcc} 0 \mathrm{f} 31 \mathrm{~d}$.

6. Kakasis A, Panitsa G. Bacteriophage therapy as an alternative treatment for human infections. A comprehensive review. Int J Antimicrob Agents. 2019;53(1):16-21. doi: 10.1016/j. ijantimicag.2018.09.004.

7. Rolain JM, Parola P, Cornaglia C. New Delhi metallobeta lactamase (NDM-1): towards a new pandemic? Clin Microbial Infect. 2010;16(12):1699-701. doi: 10.1111/j.14690691.2010.03385.x.

8. Opal SM. Non-antibiotic treatments for bacterial diseases in an era of progressive antibiotic resistance. Critical Care. 2016;20(1):397. doi: 10.1186/s13054-016-1549-1.

9. Kang JH, Super M, Yung CW, Cooper RM, Domansky K, Graveline AR, et al. Biospleen device for extracorporeal sepsis therapy. In: 18th International Conference on Miniaturized Systems for Chemistry and Life Sciences, San Antonio, Texas, USA, Oct. 26-30, 2014. Available from: https://www. rsc.org/images/loc/2014/PDFs/Papers/838_5020.pdf.
10. Kalia V. Quorum sensing inhibitors: an overview. Biotechnol Adv. 2013;31(2):224-45. doi: 10.1016/j. biotechadv.2012.10.004.

11. Brackman G, Coenye T. Quorum sensing inhibitors as antibiofilm agents. Curr Pharm Des. 2015;21(1):5-11. doi: 10.2 174/1381612820666140905114627.

12. Campos-Galvão MEM. Caracterização do mecanismo de sinalização por quorum sensing em Salmonella enterica sorovar Enteritidis [tese]. Viçosa: Universidade Federal de Viçosa; 2012. Disponível em: https://www.locus.ufv.br/ handle/123456789/1568.

13. Irani V, Guy A, Andrew D. Molecular properties of human IgG subclasses and their implications for designing therapeutic monoclonalantibodies against infectious diseases. Mol Immunol. 2015;67(2 Pt A):171-82. doi: 10.1016/j. molimm.2015.03.255.

14. Fontes OLF. Farmácia homeopática: teoria e prática. Barueri: Manole; 2014. Cap. 1, 2.

15. Furuta SE, Weckx LLM, Figueiredo CR. Estudo clínico, duplocego, randomizado, em crianças com amigdalites recorrentes submetidas a tratamento homeopático. Rev Homeopatia (São Paulo). 2017;80(1/2):164-73. Disponível em: http://revista. aph.org.br/index.php/aph/article/view/398/444.

16. Miranda JAL, Rocha JA, Araújo KM, Quelemes PV, Mayo SJ, Andrade IM. Atividade antibacteriana de extratos de folhas de Montrichardia linifera (Arruda) Schott (Araceae). Rev Bras Plantas Med. 2015;17(4 supl. 3):1142-9. doi: 10.1590/1983084x/14_169.

17. Nascimento Júnior BJ, Tínel LO, Silva ES, Rodrigues LA, Freitas TON, Nunes XP, Amorim ELC. Avaliação do conhecimento e percepção dos profissionais da estratégia de saúde da família sobre o uso de plantas medicinais e fitoterapia em Petrolina-PE, Brasil. Rev Bras Plantas Med. 2016;(18):57-66. doi: 10.1590/1983-084X/15 031.

18. Teixeira ACJ. Fitoterapia aplicada à prevenção e tratamento de infecções urinárias. Porto; 2012. Cap. 2.4. Disponível em: https://bdigital.ufp.pt/bitstream/10284/3738/1/ Fitoterapia $\% 20$ ap licada $\% 20 \%$ C $3 \%$ A $0 \% 20$ preven $\% \mathrm{C} 3 \% \mathrm{~A} 7 \% \mathrm{C} 3 \% \mathrm{~A} 3 \mathrm{o} \% 20 \mathrm{e} \% 20$ tratamento $\% 20 \mathrm{de} \% 20$ infec $\% \mathrm{C} 3 \% \mathrm{~A} 7 \% \mathrm{C} 3 \% \mathrm{~B} 5 \mathrm{es} \% 20$ urin\% $3 \% \mathrm{~A} 1$ rias.pdf.

19. Wittebole X. A historical overview of bacteriophage therapy as an alternative to antibiotics for the treatment of bacterial pathogens. Virulence. 2014;5(1):226-35. doi: 10.4161/ viru.25991. 
20. Rossi, LPR, Almeida RCC. Bacteriófagos para controle de bacterias patogênicas em alimentos. Rev Inst Adolfo Lutz. 2010;69(2):151-6. Disponível em: https://pesquisa.bvsalud. org/portal/resource/pt/lil-571125.

21. Wright A, Hawkins CH, Anggard EE, Harper DR. A controlled clinical trial of a therapeutic bacteriophage preparation in chronic otitis due to antibiotic resistant Pseudomonas aeruginosa; a preliminary report of efficacy. Clin Otolaryngol. 2009;34(4):349-57. doi: 10.1111/j.17494486.2009.01973.x

22. Azevedo AFOM. Desenvolvimento do sistema terapêutico com bacteriófagos para administração por via inalatória com recurso de nanoencapsulação, como modelo para tratamento de pneumonia bacteriana [dissertação]. João Pessoa: Universidade Fernando Pessoa, Faculdade de Ciências da Saúde; 2010. Disponível em: http://hdl.handle. net $/ 10284 / 2488$.

23. Schooley RT. Development and use of personalized Bacteriophage - based therapeutic cocktails to treat a patient with a disseminated resistant Acinetobacter baumannii infection. Antimicrob Agenty Chemother. 2017;61:e000954-

\section{7. doi: 10.1128/AAC.00954-17}

24. Sabino J, Hirten RP, Colombel JF. Review article: bacteriophages in gastroenterology-from biology to clinical applications. Aliment Pharmacol Ther. 2019 Nov 7. doi: 10.1111/apt.15557. [Epub ahead of print].

25. Abedon ST. Phage-antibiotic combination treatments: antagonistic impacts of antibiotics on the pharmacodynamics of phage therapy? Antibiotics (Basel). 2019;8(4):pii: E182. doi: 10.3390/antibiotics8040182.

26. Love MJ, Abeysekera GS, Muscroft-Taylor AC, Billington C, Dobson RCJ. On the catalytic mechanism of bacteriophage endolysins: Opportunities for engineering. Biochim Biophys Acta Proteins Proteom. 2019 Oct 30:140302. doi: 10.1016/j. bbapap.2019.140302

27. Wernicki A, Nowaczek A, Urban-Chmiel R. Bacteriophage therapy to combat bacterial infections in poultry. Virol J. 2017;14(1):179. doi: 10.1186/s12985-017-0849-7.

Received: 2019 November 10

Accepted: 2019 November 11 